\title{
Discovery Learning Based E-Module on Protein Material Development
}

\author{
Eika Abigail Munthe \\ Magister of Chemistry Education: \\ Postgraduate School \\ Universitas Negeri Medan \\ Medan, Indonesia \\ eikaabigailmunthe@gmail.com
}

\author{
Saronom Silaban \\ Departement of Chemistry Education \\ Universitas Negeri Medan \\ Medan, Indonesia \\ silabans@gmail.com
}

\author{
Zainuddin Muchtar \\ Departement of Chemistry Education \\ Universitas Negeri Medan \\ Medan, Indonesia \\ Muchtar.zai@gmail.com
}

\begin{abstract}
Modules are teaching materials that are designed to be independently studied by learning participants. This study aims to determine the eligibility of biomolecular e-module that have been developed with discovery learning models on protein material. This study uses the ADDIE development model (Analyze, Design, Develop, Implementation, Evaluation), but the research only carried out until the development stage. E-module that have been developed are validated by 3 expert lecturers. The instrument used in the study was a questionnaire on National Higher Education Standards (SNPT) consisting of content, language, presentation, and graphic eligibility. The results showed that the biomolecular e-module that had been developed with the discovery learning model on protein material was valid for college students to use.
\end{abstract}

Keywords—discovery learning; e-module; eligibility SNPT; protein

\section{INTRODUCTION}

Epistemologically, biochemistry is difficult for college students [1]. Abstract concepts that require high thinking and very limited time to deliver material have become obstacles in biochemical learning. The many concepts and characteristics possessed by biochemical subjects often lead to boredom and make the quality of the learning process low $[2,3]$.

In addition, educators also experience problems in determining the right teaching materials to use. This is because there is a lack of quality chemical teaching materials in universities that are following the curriculum or syllabus [4].

To overcome these problems, it is necessary to do repairs, changes, and updates. The procurement of quality subject matter is one of the efforts to improve the quality of education and can be done through quality teaching material. Quality teaching materials must be able to present teaching materials following curriculum demands, follow the development of science and technology and be able to bridge learning so that the specified competencies can be achieved. Lecturers as facilitators need to be more creative in developing the learning process, one of which is by innovating in the development of teaching materials, both in terms of technology and the approach adopted to be very important for the achievement of learning objectives $[5,6]$.

One type of teaching material is a module. Modules are a set of teaching materials that are presented systematically and completely so that users can learn with or without the teacher, with modules students can learn individually at school or home according to their respective learning speeds [7]. The use of modules in learning increases student achievement [7, $8,9]$.

To reduce the saturation of students learning with modules, the modules need to be combined with electronic media, which are often called electronic modules (e-module). Emodule is teaching the material in the form of a module that is displayed in an electronic format that is expected to increase students' interest and motivation to learn [10]. Based on research that has been done, the use of e-modules has been shown to increase achievement and obtain positive student responses $[11,12,13]$.

One of the applications for making an e-module is kvisoft flipbook maker [14]. Kvisoft flipbook maker is a reliable software that is designed to convert PDF files to turning pages of digital publications or digital books. This software can change the appearance of PDF files to be more attractive like a book. Also, Kvisoft Flipbook Maker can make PDF files into a magazine, digital magazine, flipbook, company catalog, digital catalog and others [15]. The use of Kvisoft flipbook maker software in learning makes the learning process more effective and obtains positive student responses [16, 17].

In addition to developing modules, learning models are also needed that can actively involve students in the learning process. Discovery Learning refers to learning that occurs when students engage in experiences and experiments, where they get their knowledge and concepts [18]. Through learning the Discovery Learning model, students are expected to be able to build knowledge based on new information and collect data in an explorative learning environment. Explorative learning environments can be realized through real experiences (experiments) that are experienced directly by students themselves so that the knowledge obtained by students will be more meaningful and relevant for students [19]. Based on several studies that have been conducted, it can 
be concluded that the application of the Discovery Learning model increases student activity, learning achievement, and generic science skills [20, 21, 22].

\section{METHOD}

This study uses the ADDIE development model (Analyse, Design, Develop, Implementation, Evaluation). The research was carried out only until the development stage. The research design can be seen in Fig. I. Research has been carried out at Universitas Negeri Medan (Unimed), Willem Iskandar Pasar V Street, Medan 20221, Sumatera Utara. The study was conducted in May until September 2019.

The population in this study were all lecturers who taught at Unimed. The sample in this study was 3 lecturers teaching biochemistry at Unimed who were selected with a purposive sampling technique with minimum S3 education criteria and had experience in the field of materials, models and learning media.

Data collection in this study using a questionnaire. Researchers used a closed questionnaire containing statements to respondents. Respondents choose one of the answers to the question by putting a checklist on the answers provided. The questionnaire used in this study was the SNPT eligibility questionnaire. Before being used, the questionnaire instrument was validated by expert lecturers. This questionnaire is used to validate student learning handbooks and discovery learningbased e-modules that have been developed.

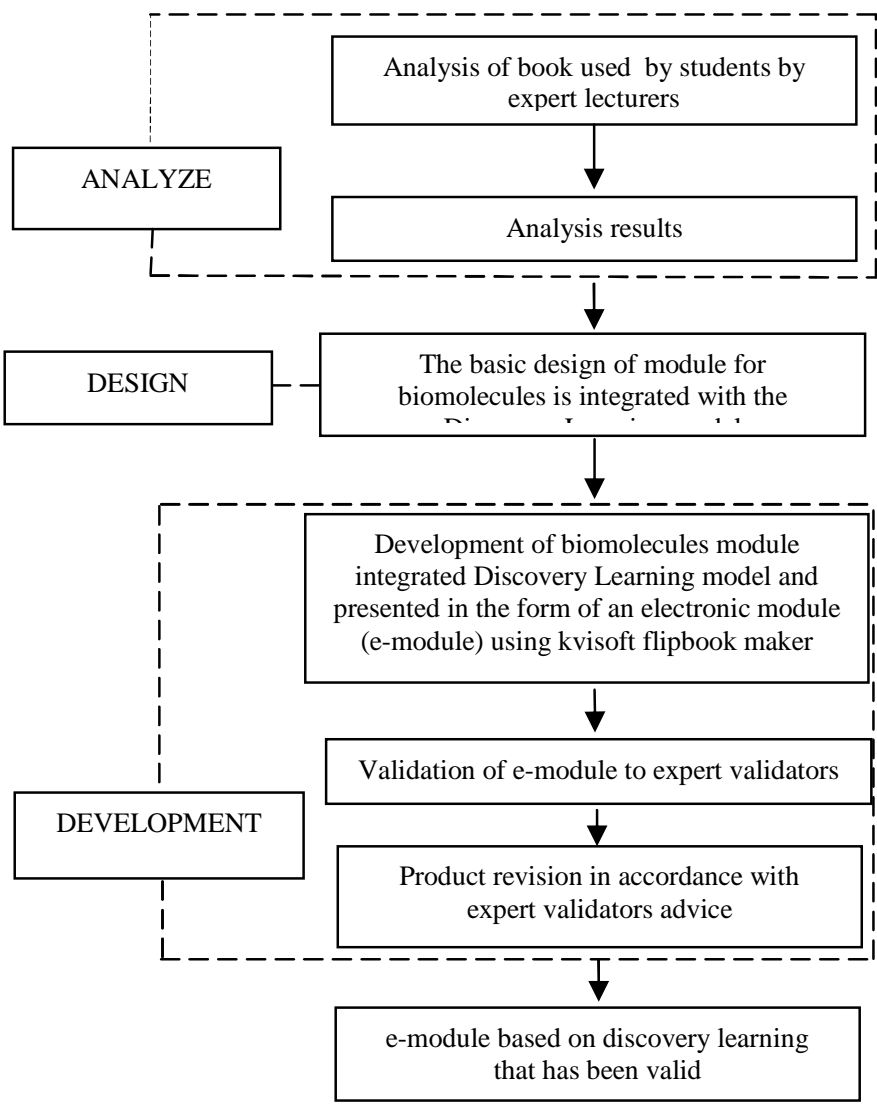

Fig I. Research Design

\section{RESULT AND DISCUSSION}

In this research, an e-module development based on discovery learning has been carried out on protein material. Before developing the e-module, first, an analysis of the student biomolecule book is used by students of the Chemistry Education Study Program, Department of Chemistry at Universitas Negeri Medan (Unimed). The questionnaire used in analyzing student handbooks and e-modules developed was the SNPT (National Higher Education Standards) questionnaire, which is a modification of the BSNP (National Education Standards) questionnaire and SNPT (National Higher Education Standards) and discovery learning models. The questionnaire consisted of 4 eligibility criteria, namely content, presentation, language and graphics eligibility. In each eligibility criteria, there are aspects contained therein. These aspects can be seen in TABLE I. Before being used, the questionnaire instrument was validated by expert lecturers. This analysis aims to determine the level of eligibility of university books and e-modules that have been developed. The average value of each aspect will indicate the level of validity of the university books and e-modules developed. Eligibility criteria for university books and e-modules are presented in TABLE II.

TABLE I. SNPT ELIGIBILITY ASPECTS

\begin{tabular}{|l|l|}
\hline Eligibility & \multicolumn{1}{|c|}{ Aspect } \\
\hline Content & $\begin{array}{l}\text { (1) Material coverage, (2) Material accuracy, (3) } \\
\text { Update, (4) Compliance with laws and regulations }\end{array}$ \\
\hline Presentation & $\begin{array}{l}\text { (1) Presentation techniques, (2) Supporting presentation } \\
\text { of material, (3) Presentation of Learning (Discovery } \\
\text { Learning), (4) Completeness of presentation }\end{array}$ \\
\hline Language & $\begin{array}{l}\text { (1) Conformity with the level of thought development of } \\
\text { students, (2) Readability, (3) Ability to motivate, (4) } \\
\text { Accuracy, (5) Coherence and wrinkling of thought flow, } \\
\text { (6) Conformity with Indonesian language rules, (7) Use } \\
\text { of terms and symbol }\end{array}$ \\
\hline Graphics & $\begin{array}{l}\text { (1) Design/Display, (2) Audio, (3) Visual, (4) } \\
\text { Animation, (5) Video, (6) Media operation }\end{array}$ \\
\hline
\end{tabular}

TABLE II. ELIGIBILITY CRITERIA

\begin{tabular}{|c|c|}
\hline Average & Eligibility Criteria \\
\hline $3,26-4,00$ & Very Feasible \\
\hline $2,51-3,25$ & Feasible \\
\hline $1,76-2,50$ & Less Feasible \\
\hline $1,00-1,75$ & Not Feasible \\
\hline
\end{tabular}

\section{A. Analysis of the Student Handbook}

The Biochemistry textbook for students in the Unimed Chemistry Education Study Program is a book written by X. Based on the results of the book analysis, the content eligibility is 2.46 (less feasible), the presentation eligibility is 2.77 (feasible), the language eligibility is 2.93 (feasible ), and the graphic eligibility is 1.05 (not feasible). The results of the analysis of the student handbook can be seen in Fig II. Based on the eligibility value, an average of 2.30 is obtained (less feasible). This shows that the book is not suitable for use. Improvements are needed in several aspects of eligibility, especially in aspects of content and graphics eligibility. The results of this study are in line with previous research which states that very few quality chemical teaching materials in 
tertiary institutions are in accordance with the curriculum or syllabus [4].

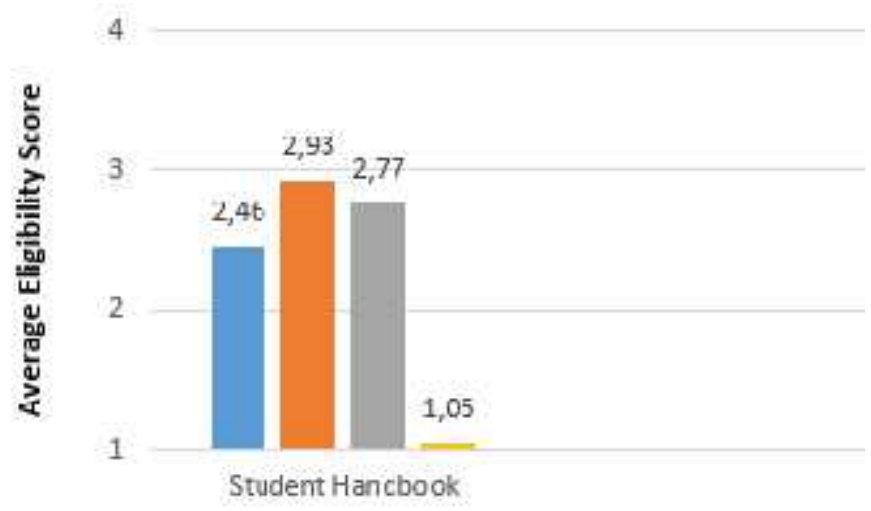

Eligibility Criteria

=Contert =Language =Presentatior =Graphics

Fig 2. The Result of The Analysis of The Student Handbook

\section{B. Discovery Learning Based E-Module on Protein Material}

Based on the results of the analysis of student handbooks, researchers have developed discovery learning based emodules on protein material. The e-module display that has been developed can be seen in Fig. III.

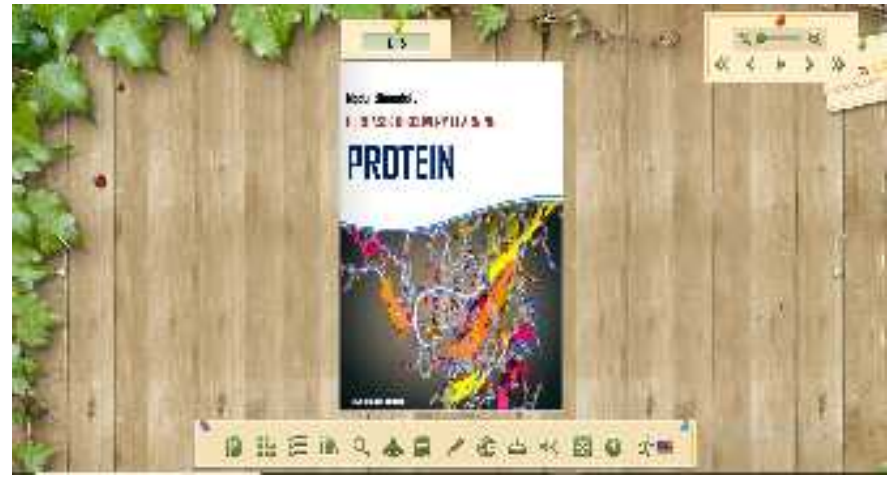

Fig 3. Display e-modules that have been developed

After being developed, researchers conducted a standard test again using the same questionnaire. The results of the SNPT eligibility test standard discovery learning based emodule on protein material by expert lecturers obtained the value of the contents eligibility is 3.65 (very feasible), the language eligibility is 3.60 (very feasible), the presenting eligibility is 3.68 (very feasible), and graphical eligibility 3.64 (very feasible). The results of the standard test discovery learning based e-module can be seen in Fig. IV. Based on the eligibility value, an average value of 3.64 (very feasible) was obtained. This shows that discovery learning based e-modules on protein material are very feasible to use. This is in line with the results of research [10] which shows the development of emodules has a very high level of validity. Furthermore [23] showed that the development of e-modules obtained very good results.

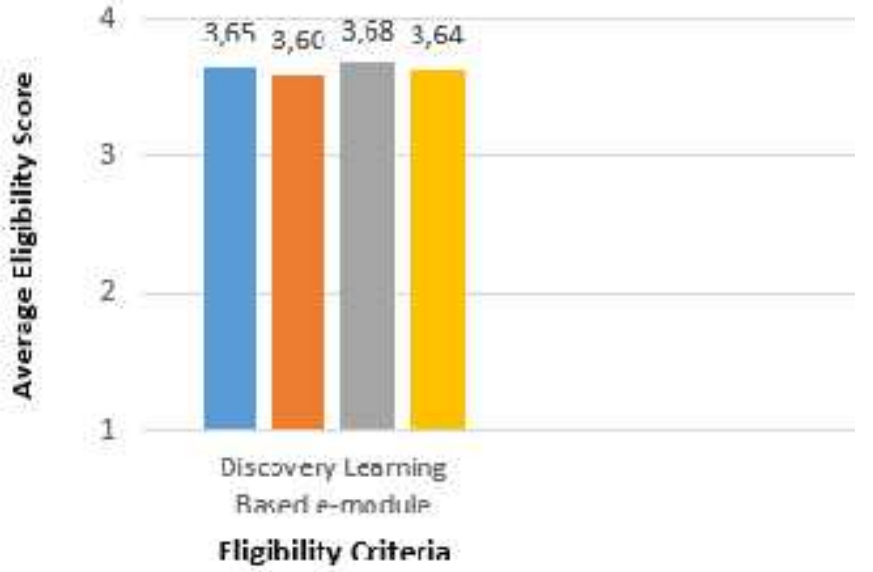

= Content in Language in Presentation it Graphics

Fig 4. The Result of The Standart Test Discovery Learning Based E-Module on Protein Material

\section{CONCLUSION}

Based on the results of data processing, it was concluded that the discovery learning based e-module on protein material that was developed was in accordance with the criteria of eligibility for the SNPT standard and was suitable for use.

\section{ACKNOWLEDGMENT}

The author would like to acknowledge Prof. Dr. Retno Dwi Suyanti, M.Si, Dr. Murniaty Simorangkir, MS, and Drs. Sriadhi, M.Pd.,M.Kom.,Ph.D who has agreed to become expert validators. Also, the author's gratitude is addressed to the head of chemistry department and dean of the faculty of mathematics and natural sciences Universitas Negeri Medan.

\section{REFERENCES}

[1] J.J. Vanderlie, "Improving the student experience of learning and teaching in second year biochemistry: assessment to foster a creative application of biochemical concepts," International Journal of Innovation in Science and Mathematics Education, vol. 21, pp. 46-57, 2013.

[2] Y.A.S. Anwar, Senam, and E.W. Laksono, "Effective laboratory work in biochemistry subject: Students' and lecturers' perspective in Indonesia," International Journal of Higher Education, vol. 6, pp. 100109, March 2017.

[3] M. Nurjayadi and I.R.Kartika, "Upaya peningkatan aktivitas mahasiswa pada pembelajaran bilingual biokimia dengan model pembelajaran cooperative learning tipe student team achievement division di jurusan kimia fmipa UNJ," JRPK, vol. 1, pp. 2253-5378, December 2012.

[4] E. Gultom, M. Situmorang and R. Silaban, "Pengembangan bahan ajar inovatif dan interaktif melalui pendekatan saintifik pada pengajaran termokimia,” Jurnal Pendidikan Kimia, vol. 7, pp. 49-56, August 2015.

[5] M. Situmorang, "Pengembangan buku ajar kimia SMA melalui inovasi pembelajaran dan integrasi pendidikan karakter untuk meningkatkan hasil belajar siswa," Prosiding Semirata Universitas Lampung, 2013.

[6] H. Fitriani, M. Situmorang and A. Darmana, "Pengembangan bahan ajar inovatif dan interaktif melalui pendekatan sainstifik pada 
pengajaran larutan dan koloid," Jurnal Edukasi Kimia, vol. 2, pp. 4853, 2017.

[7] Yerimadesi, Bayharti, F. Handayani and W.F. Legi, "Pengembangan modul kesetimbangan kimia berbasis pendekatan saintifik untuk kelas XI SMA/MA,” Journal of Sainstek, vol. 8, pp. 85-97, 2016.

[8] K. Osman and L.T. Tien, "Impact of interactive multimedia module with pedagogical agents on students' understanding and motivation in the learning of electrochemistry," International Journal of Science and Mathematics Education, vol. 12, pp. 395-421, March 2013.

[9] E. Lokaria, "Pengaruh penggunaan modul biokimia pada mahasiswa pendidikan biologi STKIP-PGRI Lubuklinggau," Jurnal BIOEDUKATIKA, vol. 1, pp. 23-26, September 2016.

[10] Asmiyunda and F. Azra, "Pengembangan e-modul kesetimbangan kimia berbasis pendekatan saintifik untuk kelas XI SMA/MA, Jurnal Eksakta Pendidikan, vol. 2, pp. 155-161, November 2018.

[11] Suyoso and S. Nurohman, "Pengembangan modul elektronik berbasis web sebagai media pembelajaran fisika," Jurnal Kependidikan, vol. 1, pp. 73-82, 2014.

[12] A. Zulkarnain, N. Kadaritna and L. Tania, "Pengembangan e-modul teori atom mekanika kuantum berbasis web dengan pendekatan saintifik," Jurnal Pendidikan dan Pembelajaran Kimia, vol. 1, pp. 222235, April 2015.

[13] H. Zulvianda, L. Hanum and M. Nazar, "Pengembangan e-modul kimia SMA pada materi larutan elektrolit dan non elektrolit," Jurnal Ilmiah Mahasiswa Pendidikan Kimia, vol. 3, pp.9-16.

[14] E. Wibowo and D.D. Pratiwi, "Pengembangan bahan aja menggunakan aplikasi kvisoft flipbook maker materi himpunan,' Desimal: Jurnal Matematika, vol. 1, pp. 147-156, Mai 2018.

[15] N.N. Mulyaningsih and D.L. Saraswati, "Penerapan media pembelajaran digital book dengan kvisoft flipbook maker," Jurnal Pendidikan Fisika Universitas Muhammadiyah Metro, vol. 1, pp. 2532, 2017.

[16] Rasiman and A.S. Pramasdyahsari, "Development of mathematics learning media e-comic based on flipbook maker to increase the critical thinking skill and character of junior high school students," International Journal of Education and Research, vol. 11, pp. 535-544, November 2014

[17] D.T. Andani and M. Yulian, "Pengembangan bahan ajar electronic book menggunakan software kvisoft flipbook pada materi hukum dasar kimia di SMA N 1 Panton Reu Aceh Barat," Jurnal IPA dan Pembelajaran IPA, vol. 2, pp. 1-6, 2018.

[18] R. Puspitadewi, A.N.C. Saputro and Ashadi, "Penerapan mode pembelajaran discovery learning untuk meningkatkan minat dan prestasi belajar siswa pada materi kelarutan dan hasil kali kelarutan kelas XI MIA 3 semester genap SMA N 1 teras tahun pelajaran 2015/2016," Jurnal Pendidikan Kimia, vol. 5, pp. 114-119, 2016.

[19] H. Kurnianto, M. Masyukri and S. Yamtinah, "Pengaruh mode pembelajaran discovery learning disertai Lembar Kegiatan Siswa (LKS) terhadap prestasi belajar siswa pada materi hidrolisis garam kelas XI SMA Negeri 1 Karanganyar tahun pelajaran 2014/2015, vol. 5, pp.32-40.

[20] G.A. Istiana, A.N.C. Saputro and J.S. Sukardjo, "Penerapan mode pembelajaran discovery learning untuk meningkatkan aktivitas dan prestasi belajar pokok bahasan larutan penyangga pada siswa kelas $\mathrm{x}$ ipa semester ii sma negeri 1 ngemplak tahun pelajaran 2013/2014,' Jurnal Pendidikan Kimia, vol. 4, pp.65-73, 2015.

[21] E.N.Khabibah, Maridi and M. Masyukri, "The effectiveness of module based on discovery learning to increase generic science skills," Journal of Education and Learning, vol. 11, pp. 146-153, 2017.

[22] D. Atika, M. Nuswowati and S. Nurhayati, "Pengaruh metode discovery learning berbantuan video terhadap hasil belajar kimia siswa SMA,” Jurnal Inovasi Pendidikan Kimia, vol. 12, pp. 2149-2153, 2018.

[23] T. Solihudin, "Pengembangan e-modul berbasis web untuk meningkatkan pencapaian kompetensi pengetahuan fisika pada materi listrik statis dan dinamis SMA," Jurnal Wahana Pendidikan Fisika, vol 3, pp. 51-61, September 2018. 